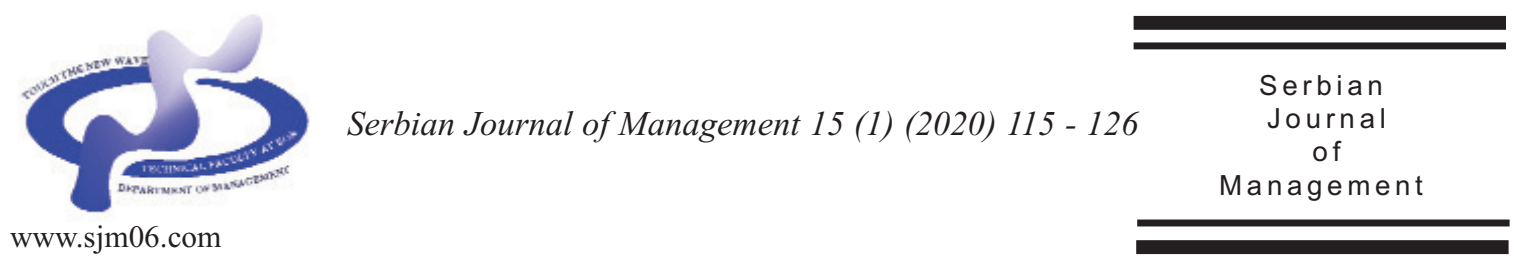

\title{
DIGITAL COMPETENCIES IN MANAGEMENT: A WAY TO SUPERIOR COMPETITIVENESS AND RESISTANCE TO CHANGES
}

\author{
Valentina Vasilievna Gerasimenko* and Tatiana Olegovna Razumova \\ Lomonosov Moscow State University, Economic Faculty, \\ Leninskiye Gory 1, Building 46, r. 346, 372, 119991 Moscow, Russia
}

(Received 03 November 2019; accepted 16 March 2020)

\begin{abstract}
Digital technologies in management of companies are becoming a necessary condition for their competitiveness. The use of these technologies requires changes in management processes and in the organization of managers' work. The authors have looked into the usage of digital technologies and problems which Russian managers face when dealing with them, and into the attitudes to digital technologies that reveal the existing challenges, including the resistance to the oncoming changes. The paper analyzes the issues related to the ways of building new managerial competences in digital economy.
\end{abstract}

Keywords: digitization, data economy, digital competence, digital business models

\section{INTRODUCTION}

In its 2006 Recommendations, the European Parliament (Recommendations) states that the digital competence is one of the eight key competences of life-long learning. Digital competence is a transversal key competence that allows people to acquire other key competences, such as language, mathematics, learning or cultural awareness. It is closely connected with many of the so called XXI century skills, which need to be mastered by all citizens to ensure their ability to actively participate in the social and economic life (Ferrari, 2012).

Digital competence is both one's right and one's obligation if the person is to function in the modern society. However, people do not always keep up with the changing requirements brought about by fast technological change and by the need to act in the new working environment. This

\footnotetext{
* Corresponding author: vv_gerasimenko@mail.ru
}

DOI: $10.5937 /$ sjm 15-23865 
certainly relates to digitization of management, which demands that managers acquire digital competences to match the new level of digital technologies. The paper explores the development of the relevant processes.

Full digitizing of goods and services coupled with advanced analytics affects the dynamics of business models (BM) and requires that entrepreneurs adjust their managerial abilities to dealing with challenges that arise because of new client needs, new rules and mounting privacy issues. A research by Gauthier et al. (2018) has shown that entrepreneurs need three major types of managerial abilities: information technologies (IT) to resolve internal issues, strategic abilities to address external challenges, and BM-specific abilities to manage the input/output interface. Managerial potential is formed by the competences that help entrepreneurs to create, expand and improve their business practices. This potential has been traditionally seen as involving three types of capital: (a) managerial human capital, industry-specific expertise and particular skills; (b) managerial social capital and expertise in managing internal and external relationships of the company; (c) managerial knowledge, i.e. mindsets and attitudes that facilitate decision-making processes. Latest research into BMs indicate the need for understanding the degree in which business models of Uber-shaped markets and Googletype platforms require a new set of managerial abilities and a different potential of thinking and acting.

Thomas Süße et al. (2018) have shown that digital competence is supported by several parameters, or particular aspects, most relevant for Product-Service Systems (PSS), such as critical perception and problem-oriented recombination of information and knowledge from digital sources. The scale of measuring such digital competence should make these aspects more operational. The empirical research carried out by these authors allows them to determine the three corresponding sub-levels of digital competence, which can be named "technical processing", "critical assessment" and "problem-oriented use" of digital information.

Classical managerial abilities are no longer sufficient for attaining the necessary levels of digital competence. Today, entrepreneurs need to be capable of using disruptive innovations, managing network effects or maintaining control over an ecosystem's digital architecture in order to create value.

Mastering digital competences is especially important for skills development and additional training of the groups of population that need these kinds of education (Gerasimenko et al., 2015; Pięta, 2018). It has become perfectly clear why digital competences are included by the European Parliament in the list of eight competences, crucial for the process of life-long learning.

\section{DIGITALIZATION AND NEW ORGANIZATION OF MANAGERIAL WORK}

In the last few years, concerns have been growing over socioeconomic consequences of full development and utilization of digital technologies among the members of scientific and political community at the European and global level. Declines in employment caused by digitalization of production and management are seen as a major threat. 
The studies that have been completed by now mostly aim to determine the number of jobs, in which human labour may be replaced by machines. According to their estimates, about $30-40 \%$ of jobs in economically advanced countries will be threatened over the nearest 15-20 years. Some researchers (Valenduc \& Vendramin, 2016) point out that these forecasts are based on the assumption that there is "a direct causal relationship between technological innovation (e.g. machine learning and mobile bots) and productivity growth." These authors argue that the existence of such causal relationship can and should be contested.

Impressive digital achievements have received so much researchers' attention and media coverage, that now it is widely believed that technology always raises productivity and computers and robots are being demonized as they presumably cause massive job losses, especially in processing industries. A more detailed and thorough analysis of the processes underlying job creation and job losses has shown that technologies are often used as a pretext or possibility to carry out industrial restructuring.

Computers, internet and state-of-the art digital technologies are being introduced by businesses unevenly, depending on their size, location, type of work and place in the valuechains. Productivity growth is caused not only by new technologies but also because of changes in organization and labour, which may be driven by their use (Freddi, 2017). Robot design, maintenance and repair certainly create jobs, but equally important are the new kinds of activity which develop as a result of increased leisure time and the need to organize it (Acemoglu \& Restrepo, 2017).

As far as management of business organizations is concerned, digitization is already seen as a necessary condition for their competitiveness, regardless of size and area of work. That is why digitalization in business management and marketing has recently become an object of scientific study (Gerasimenko, 2019). Since digital transformation simultaneously occurs in several areas of organization's activity, there are many parties involved in defining the strategy of this transformation, among them marketing, IT, HR, product and strategy design teams. All these groups need to develop common understanding of priorities for digitization-related actions. Besides, digital transformation has had different effects in different industries. At first, it seemed that digitization will primarily affect B2C areas with more client-oriented businesses, rather than organizations working along "business-to-business" (B2B) lines. It is now clear, however, that digital technologies are being actively introduced in all spheres of management. The process of strategic transformation includes the working out of a vision, strategic planning and implementation.

Today many firms from all spheres of business are working hard on designing a viable strategy of digital transformation. For this purpose, their managers need to make decisions about the elements of the "transformation road map", set priorities in terms of various types of activities and develop strategic vision of the digital era. To design the digital transformation strategy, managers require a tool that could help them detect possible areas of action and understand the phenomena in question. This tool should also serve as a boundary facility for transmission of goals between the parties involved. In order to determine the strategy of digital transformation, managers need to 
have a clear idea of the current state of their organization. Although transformation is a non-linear process, various options are possible. It would be useful for business leaders to be aware of the difficulties related to this or that option if they are to make wellinformed decisions about setting priorities at different stages and build foundation for successful organizational change. Empirical research by Berghaus and Back (2016) has shown that most business organizations are already using digital technologies in the process of management. Yet, in terms of personalized client experience, the results generated on the basis of big data analysis or process automation have not so far been spectacular.

It follows that businesses aiming to digitize their management systems have to initiate changes in both their internal structures and business models, which no doubt involves complicated training. All this presents new challenges for business schools, as they will have to introduce changes in the content and technologies of teaching, taking into account the global digitization processes in management (Gerasimenko \& Molchanova, 2017).

In the Russian economy digital transformation is a fast-developing process. It affects all spheres of management and is widely discussed by experts. Managers and experts are talking about the same processes and controversial issues as their international colleagues. Particular attention is paid to the ways of digitizing management and marketing, the problem of resistance to change and the challenges that business managers face in the context of the digitizing world. All these issues require in-depth research and analysis.

\section{METHODOLOGY OF RESEARCH}

In order to find out the degree in which Russian managers are aware of the beneficial effects of digitization and what competences they are developing, in January-March 2020 the authors of the present Paper conducted a survey of the managers who have attended MBA programmes at Lomonosov Moscow State University. it was used the method of questionnaire survey of the most advanced managers who are studying at or have completed MBA programmes on Strategic Management, Strategic Finance, Strategic Marketing, Human Resources Management. A total of 128 participants responded to the survey, including $44 \%$ directors and top managers, 30\% Heads of Department and $26 \%$ senior managers. When planning the survey at the University, it was proceeded from the assumption that Lomonosov MSU is a leading university in the Russian Federation which also has high international rankings and that its MBA graduates are among the most advanced managers possessing most up-to-date competences and high level of knowledge. The aim of the survey was to find out how these leaders of Russian management see the content, contemporary significance and implementation of digital technologies and how they assess their competences and the risks involved.

$53 \%$ of respondents came from the largest cities of the country, Moscow and SaintPetersburg (the so called northern capital), in which a significant proportion of the Russian business is located. $39 \%$ of respondents represented Russian regions and 8\% Russian businesses abroad. As a result, it became possible to take account of management and entrepreneurship in the Russian regions. The range of industries was 
also wide: $32 \%$ of participants work in manufacturing, 48\% - in services, including trade, financial and IT services, 18\% - other spheres, e.g., federal, regional and municipal governments.

\section{RESULTS AND DISCUSSIONS}

It was important to know first of all how the managers themselves saw the overall picture of implementing digital technologies in the management organizations that operate in different industries and different locations. In this case it was interesting to have their view of the contemporary level of using digital technologies in the firms that work in Russia. So they were offered the following question: "Suppose there is an organization in your market, which exploits digital technological potential as fully as it is currently possible, what then would be your assessment of using digital technologies in your firm?" (Figure1).

It should be noted that only $8 \%$ see the situation as excellent and $39 \%$ as good. Over half of respondents, $53 \%$, consider the actual use of digital technologies in their firms to be satisfactory $(31 \%)$ or even unsatisfactory $(23 \%)$. Over the last three years, the most successful application of digital technologies has been observed in customer service through corporate website (27\%) and in managing relations with clients using CRM systems (21\%). As for all other spheres, including the crucial logistics management, they are still digitally underdeveloped (Figure 2).

In most organizations where digital technologies were implemented in management and marketing, the management think that the effect meets the expectations $(58 \%)$ or even exceeds the expectations $(10 \%)$, i.e. the results have been found generally positive (Figure 3).

This makes one think about the pace of digital change and contradictions that occur in the course of implementing digital decisions. If their efficiency is so highly rated by managers, the question is bound to arise, why the transition to digital technologies has been so slow, according to the judgment of those very managers? What hinders the process: technological limitations

\footnotetext{
Suppose there is an organization in your market, which exploits digital technological potential as fully as it is currently possible, what then would be your assessment of using digital technologies in your firm?
}

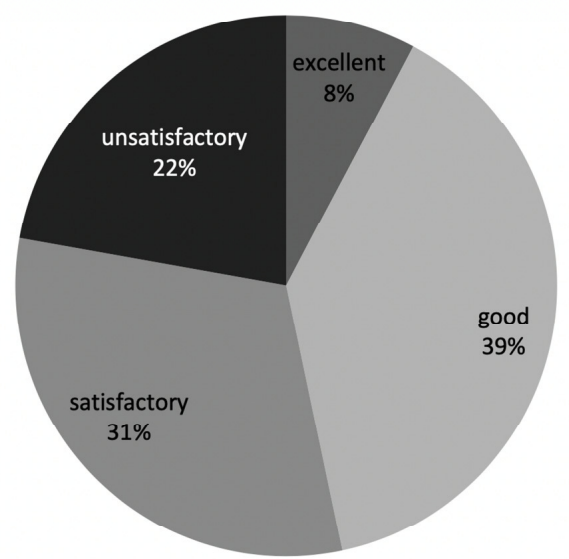

Figure 1. Assessment of the level of using digital technologies by managers of organizations 
In what areas of management and marketing has your organisation implemented digital decisions over the last three years?

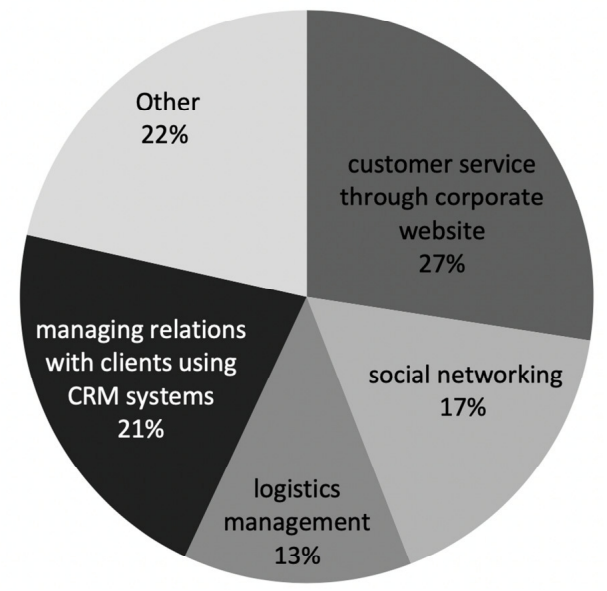

Figure 2. Most digitized areas of management

Assessment of effect from digital decisions in management and marketing

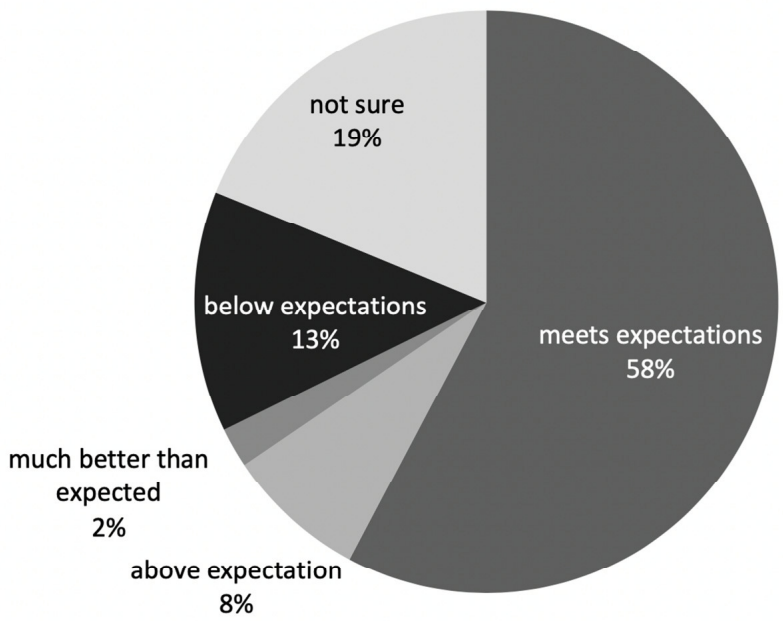

Figure 3. Application of digital technologies in management and marketing: efficiency assessment

or people who are to use them? Why do obstacles appear? Answers to these complicated and controversial questions, also discussed in the academic literature we have been referring to, were expected to be obtained from the managers who took part in our survey.

Business practitioners consider the range of available digital technologies that can be applied in management and marketing to be rather wide. First of all, they mean big data and business analytics, the use of social networks in marketing, mobile technologies in marketing, multichannel technologies of trade and marketing. Cloud technologies, dialog interface, artificial intelligence, machine learning, virtual and augmented reality are all being introduced into business activity (Figure 4).

In other words, the range of digital 


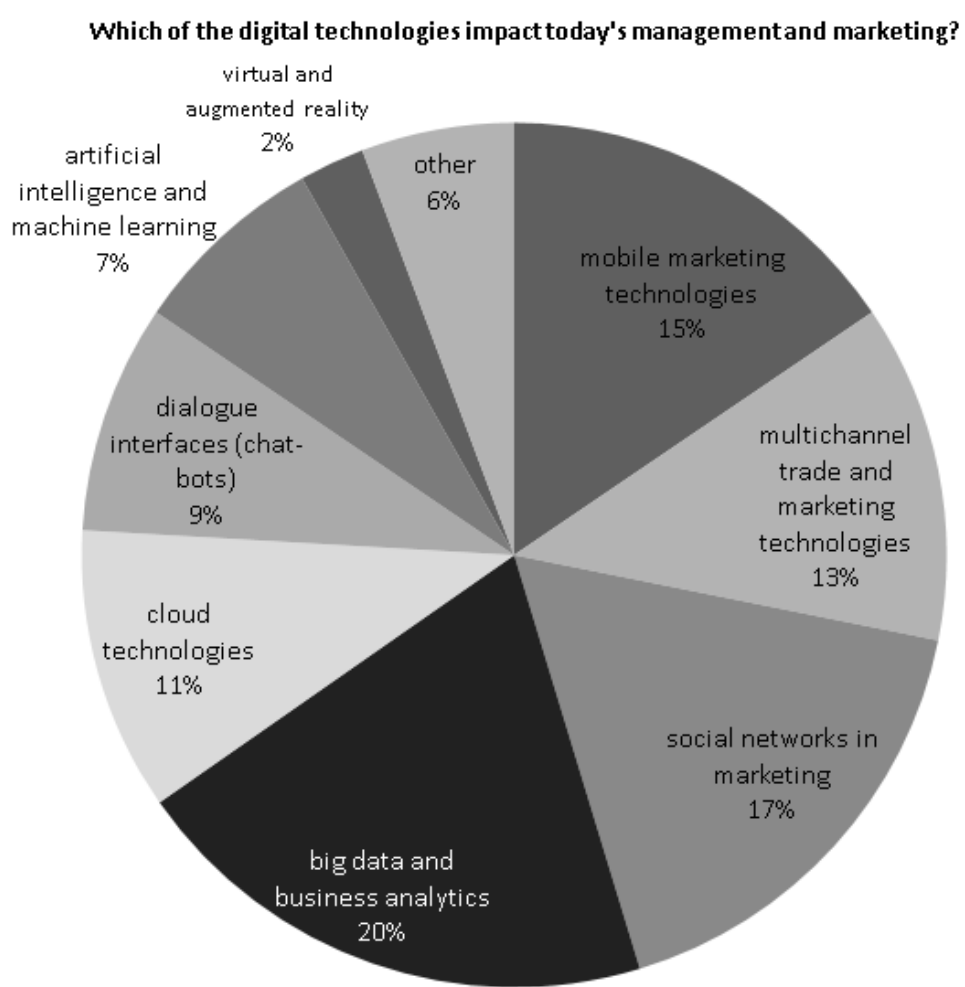

Figure 4. Assessment of the range of digital technologies in management and marketing

technologies, available to managers and currently implemented, is rather wide. The level of mastering these technologies, however, and managers' willingness to use them is still insufficient (Figures 5,7).

Hence there is the need to analyze the causes of obstacles to management digitization and search for ways to overcome these obstacles. As the survey has shown, many managers tend to think that the slow digitization of management is caused by lack of relevant information (fig.5). Only 14\% of respondents indicated that they had the knowledge necessary for adopting digital methods in their work. The others pointed out a lack of information (79\%); many of them gave priority to other factors of business development. Yet, when asked about their own organization, the survey participants became much more cautious in their assessment of the relevance of digital technologies: only $16 \%$ of respondents believe that digitization of management and marketing helps businesses become market leaders and $13 \%$ think that these technologies lead to discovering new areas of operation (Figure 6).

Apparently, the reasons for these cautious assessments are rooted not so much in technologies as in the people, including the managers of organizations. What really matters is the actual level of their digital competence, the awareness of digitizationrelated risks and prospects of improving competitiveness. In this regard, it is interesting to analyze how the survey participants see the problems faced by managers and marketers when using digital technologies (Figure 7).

The assessments obtained as a result of the survey show quite clearly that in the process of management digitization, the 
In your opinion, are the specialists of your organisation sufficiently aware of the possibilities of implementing digital technologies in its management and marketing?

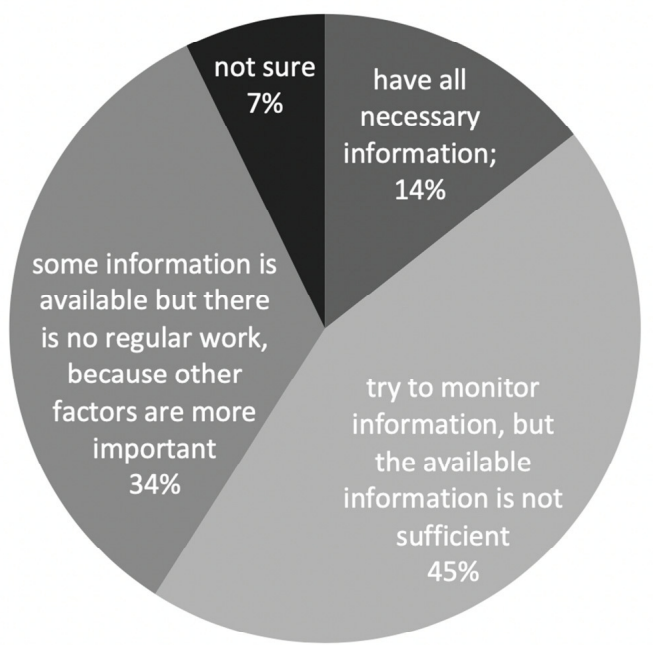

Figure 5. Assessment of managers and marketers' awareness about possibilities of using digital technologies

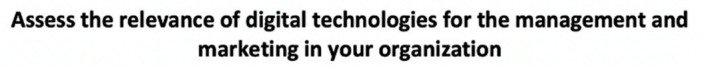
marketing in your organization

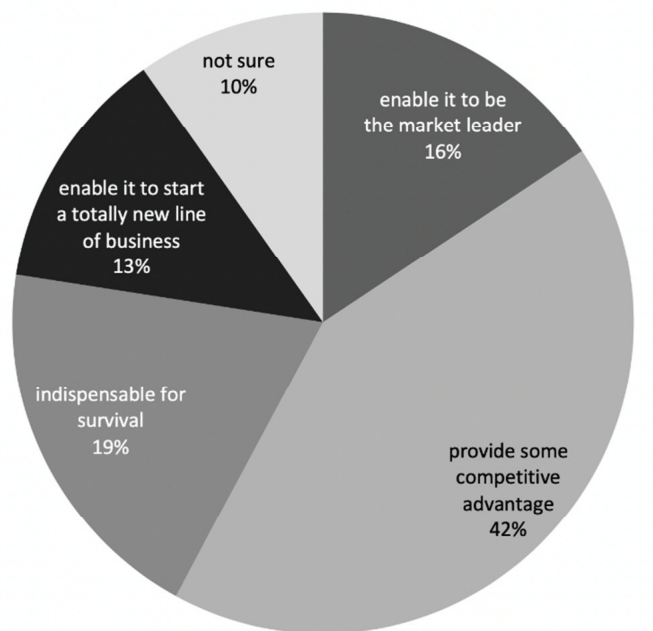

Figure 6. Assessment of the relevance of digital technologies for the management of organization

major risks arise from employees' level of knowledge and competences.

Some of the Russian surveys have shown that over $80 \%$ of businesses regard digital transformation as a critical challenge (Koptilov,2019). Yet, the wish to transform is not always based on proper understanding, which most frequently explains implementation failures. Any transformation will remain a utopian idea unless it is linked to the real needs, objectives and problems of enterprises. If it is not, the firm may at best 


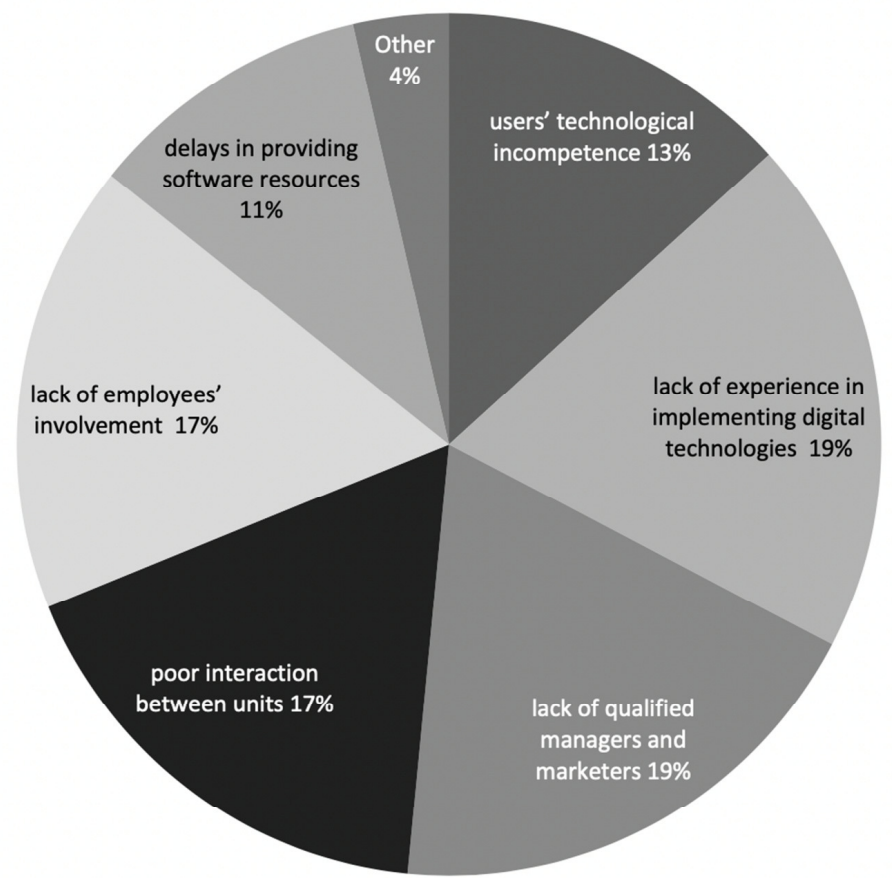

Figure 7. Assessment of problems faced by managers and marketers when using digital technologies

acquire a new vision of its business model, but with the "old-time" processes and way of thinking this will only result in having more costly and complicated tools of implementation.

At the same time, this research has allowed to see certain challenges associated with the introduction of digital technologies in management. This is not only about above mentioned critical perception and recombination of information and knowledge, but also resistance to change in management. The existence of this resistance to change is confirmed by Russian business experts. According to experts' findings, employees of many organizations are still unprepared for digital transformation (Dudareva, 2018). Sometimes, the top management initiates change, but middle managers do not support this and the line staff are totally baffled and confused. The worst situation occurs when management ignores the problems hoping that they will somehow sort themselves out. In most cases, things become even worse, the ongoing changes seem scary and people take to sabotage or have to quit.

In other countries, companies that implement digital technologies have similar difficulties: "The biggest barrier to getting technology rolled out is the organizational resistance to adoption," said Erik Brynjolfsson, director of the Initiative on the Digital Economy at the Massachusetts Institute of Technology. "So companies need a strategy not only for how to get it to work, but also how to get the work force behind getting it rolled out." (Condliffe, 2019).

It is crucial that digitizing the management of different production and 
marketing stages be coordinated. The leading experts always emphasize this principle. Thus, the director of the Russian Association of Internet of Things Andrei Kolesnikov points out that while digitization of an individual enterprise can increase efficiency by "several percentage points" it is more important to digitize two more elements: interaction with suppliers of components, materials, chemicals, energy, transport and all the inputs of a product, as well as everything connected with sales (feedback from customers, service, etc.). "Material things are not the problem. Problems are in the mindsets of people and organization of the processes." (Smirnov, 2019).

So, different studies in Russia and abroad supports main results of the research presented in this paper, concerning the direction and challengers of the digitization in management.

\section{CONCLUSIONS}

The study indicates a rapid, albeit uneven, digitization of management in Russian companies. This allows to see the development of new technologies, changes in organization, labour and competencies in Russian management, as noted in the introduction of this article in relation to foreign companies. This conclusion is supported by other Russian experts, among them Smirnov (2019) and Balenko (2019), who have shown that the main factors forcing businesses to digitize are the changing customer preferences (55\%), prospects for development in the new markets (53), rising competitive pressure (49\%). The new technologies are expected to help them gain market share, increase earnings, reduce costs, rebuild or diversify the business, leap ahead of competition, and sometimes change themselves completely. On the whole, what is in common in this research with the previous studies mentioned above (Ferrari, 2012; Freddi, 2017; Gauthier et al., 2018; Dudareva, 2018, etc.) - the crucial impact of the specific managerial competencies for digitizing of business. The main results, concerning rather uneven level of digital processes in modern Russian enterprises stated by managers themselves though they consider digitalization as a main factor of competitiveness are quite in line with (Koptilov, 2019; Smirnov, 2019).

Solutions to the problems connected with digital transformation of management lie in two directions. The first, which in this case is most important, means to be open, to explain the changes, to give, as early as possible, exhaustive information about their aims, effects and impact on individual workers, specifying who will gain from it and how much they will gain. Secondly, it is necessary to remove barriers on the way to change. One example of such barriers may be different motivation of the employees, when one person is to meet one kind of target, others have other kinds, and in the context of digital change all their targets get changed, too. Such misalignment may seriously hamper the adoption of digital technologies.

Some limitations of this research are related to the specific feature of our survey all our respondents are the actual or former students of the MBA programs in Moscow State Lomonosov University, so, the authors are aware of the fact that they get biased results of the best managers from the most developed companies. On this basis, further research should be oriented on creation of more diverse sample of respondents, including management in small and medium 
business, enlarging the share of managers outside of capital city Moscow and SaintPetersburg, that is extremely important for countries with its high regional differentiation to define the particular problems in digitizing of different types of business.

Before starting the change, one needs to understand that digitization of management is not a panacea, it cannot solve all the problems of a business. This survey and works by other researchers indicate that in many organizations managers do not fully appreciate the difficulties involved in this process. In this context, the management most urgently needs, first, to develop managers' digital competence; second, coordinate digital interaction between different levels of management; third, find ways to motivate managers properly. All these aspects of digitizing the management of business organizations should be the subject of further economic research.

\section{References}

Acemoglu, D., \& Restrepo, P. (2017). Robots and Jobs: Evidence from US Labor Markets. No 23285, NBER Working Papers, National Bureau of Economic Research, Inc. Retrieved from https://EconPapers.repec.org/RePEc:nbr:nbe rwo: 23285

Balenko, E. (2018). Industry stinted on digitalization, Technology and media. 117 (2841) (0307). Retrieved from https://www.rbc.ru/newspaper/2018/07/03/5 b3a26a89a794785abc9f304

Berghaus S., \& Back A. (2016). Stages in Digital Business Transformation: Results of an Empirical Maturity Study. MCIS 2016 Proceedings. 22. Retrieved from http://aisel.aisnet.org/mcis2016/22

Condliffe, J. (2019). The Week in Tech: Some Workers Hate Robots. Retraining May Change That. The New York Times. Retrieved from https://www.nytimes.com/2019/07/19/techn ology/amazon-automation-labor.html

Dudareva D. (2018). Innovation in the Office: How to Overcome Employee Resistance (in Rissian). Retrieved from

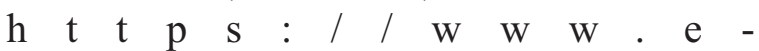
xecutive.ru/management/practices/1989419vnedrenie-innovatsii-v-ofise-kak-preodoletsoprotivlenie-sotrudnikov

Ferrari, A. (2012). Digital Competence in Practice: An Analysis of Framework. Institute for Prospective Technological Studies (Joint Research Centre), Retrieved from https://op.europa.eu/en/publicationdetail/-/publication/2547ebf4-bd21-46e888e9-f53c1b3b927f/language-en

Freddi, D. (2017). Digitalisation and employment in manufacturing. AI \& Society 33, 393-403.

Gauthier, C., Bastianutti, J., \& Haggège, M. (2018). Managerial capabilities to address digital business models: The case of digital health. Strategic Change. 27 (2), 173-180.

Gerasimenko, V. (2019). Value creation through digital technologies in product development on Russian telecommunications markets. Proceedings of the 7th International Conference Innovation Management, Entrepreneurship and Sustainability (IMES 2019), Prague, 220228.

Gerasimenko, V., \& Molchanova, O. (2017). Global pressure or national identity: strategic challenges for Russian business schools. Serbian Journal of Management, 12 (1), 133-141.

Gerasimenko, V., Razumova, T., \& 


\title{
ДИГИТАЛНЕ КОМПЕТЕНЦИЈЕ У МЕНАЏМЕНТУ: ПУТ КА СУПЕРИОРНОЈ КОНКУРЕНТНОСТИ И ОТПОР ПРОМЕНАМА
}

\author{
Valentina Vasilievna Gerasimenko, Tatiana Olegovna Razumova
}

Извод

Дигиталне технологије у управљању компанијама постају неопходан услов за њихову конкурентност. Употреба ових технологија захтева промене у управљачким процесима и у организацији рада менаџера. Аутори су проучавали употребу дигиталних технологија и проблеме са којима се руски менаџери суочавају када са њима раде, као и ставове према дигиталним технологијама који откривају постојеће изазове, укључујући отпор на надолазеће промене. У раду су анализирана питања везана за начине изградње нових управљачких компетенција у дигиталној економији.

Кључне речи: дигитализација, економија података, дигитална компетенција, дигитални пословни модели

Echenike, V. (2015). Rethinking further professional education: search for multidisciplinary and new technological approaches/ - Proceedings of 9th International Technology, Education and Development Conference (INTED2015), IATED Academy Madrid, Spain, 3270-3276.

Koptilov, A. (2016). Is your business ready for digital transformation? (in Russian). Retrieved from https://www.executive.ru/management/itforbusiness/1985 479-gotov-li-vash-biznes-k-tsifrovoitransformatsii

Pięta, P. (2018). Development of social capital by strengthening of digital competences among groups exposed to social exclusion. Annals of Marketing Management \& Economics 4 (1), 73-87.

Recommendation of the European Parliament and of the Council of 18 December 2006 on key competences for lifelong learning. (2006).Official Journal of the European Union, L 394/11.

Smirnov, A. (2019). 5 mistakes carried away by digital transformation. Retrieved from

https://www.executive.ru/management/itforbusiness/1989 903-5-oshibok-uvlechennyh-tsifrovoitransformatsiei?utm_campaign $=1605 \& u t m$ medium $=$ menedzhment\&utm_source $=$ emai

Süße, T., Wilkens, U., Hohagen, S., \& Artingerb, F. (2018). Digital competence of stakeholders in Product-Service Systems (PSS): Conceptualization and empirical exploration. Procidings of the 10th CIRP Conference on Industrial Product-Service Systems, IPS2 2018, 29-31 May, Linköping, Sweden.

Valenduc, G., \& Vendramin, P. (2016). Work in the digital economy: sorting the old from the new. ETUI Working Paper 2016:03. 